\title{
Keating v. Superior Court: Opressive Arbitration Clauses in Adhesion Contracts
}

In Keating v. Superior Court, ${ }^{1}$ the California Supreme Court recognized a new form of arbitration ${ }^{2}$ that combined in one proceeding the claims of an entire class of disputants. Keating involved individual and class suits by franchisees of a cham convemence store challenging the validity of an adhesive arbitration clause in their franchise agreements. The court found that the arbitration clause was not oppressive and was therefore valid as to the franchisees individually. However, the court recognized that the arbitration clause might be oppressive and therefore invalid to the extent that it foreclosed the franchisees' ability to bring an otherwise appropriate class proceeding. To remedy this class oppression and to further the policies underlymg private arbitration and judicial class actions, the Keating court created the classwide arbitration procedure and ordered the trial court to determine whether the procedure was appropriate for the plaintiffs' claims.

Part I of this Note presents the facts of Keating and summarizes the majority and dissenting opinions. Part II sets forth the relevant existing law of commercial arbitration, adhesion contracts, and class actions. Part III analyzes the inipact of the court's decision on the current law. It argues that while the court was correct in recognizing that an adhesive arbitration clause inight be oppressive to an entire class, the court's creation of the classwide arbitration remedy was ill-advised. Finally, Part IV proposes a test for determining whether an arbitration clause is oppressive to an entire class. It concludes that when a trial court finds an arbitration clause oppressive, the appropriate remedy is the traditional class action, not classwide arbitration.

l. 31 Cal. 3d 584, 645 P.2d 1192, 183 Cal. Rptr. 360 (1982), prob. juris. postponed to merits sub nom. Southland Corp. v. Keating, 103 S. Ct. 721 (1983) (No. 82-500).

2. Classwide arbitration has previously been allowed only in state administrative proceedings where the statutory language provided for arbitration on a class basis. See Stevenson v. Commonwealth Dep't of Revenue, 489 Pa. 1, 5, 413 A.2d 667, 669 (1980); Boynton v. Carswell, $238 \mathrm{Ga} .417,419,233$ S.E.2d 185, 187 (1977), overnuled on other grounds by Callaway v. Carswell, 240 Ga. 579, 242 S.E.2d 103 (1978). 


\section{A. The Facts}

In May 1977, Richard Keating, a California 7-Eleven convenience store franchisee, commenced a class action ${ }^{3}$ against Southland Corporation, his franchisor, alleging that Southland had violated the disclosure requirements of the California Franchise Investment Law. ${ }^{4}$ Southland invoked an arbitration provision in the franchise agreements ${ }^{5}$ as a defense to the class suit and to several similar individual actions by other franchisees which were then pending. ${ }^{6}$

The franchisees challenged the arbitration provision in the franchise contracts on three grounds: (1) that claims under the Franchise Investment Law are not subject to arbitration as a matter of law; (2) that Southland had waived its right to compel arbitration by delaying its request for arbitration and by pursuing legal reniedies inconsistent with arbitration; and (3) that the franchise contracts were unenforceable contracts of adhesion. ${ }^{7}$

\section{B. The Majority Opinion}

The court ${ }^{8}$ accepted the franchisees' argument that claims under the Franchise Investment Law $^{9}$ are not subject to arbitration. ${ }^{10}$ It held

3. The class was composed of approximately eight hundred California 7-Eleven franchisees. 31 Cal. 3d at 592, 645 P.2d at 1195, 183 Cal. Rptr. at 363.

4. CAl. CoRP. CODE $\$ \$ 31000-31516$ (West $1977 \&$ Supp. 1983). Plaintiffs also alleged fraud, oral misrepresentation, breach of contract, breach of fiduciary duty, and unfair and inaccurate accounting procedures. $31 \mathrm{Cal}$. 3d at 592, 645 P.2d at 1195, 183 Cal. Rptr. at 363.

5. Id. at 592, 645 P.2d at 1196, 183 Cal. Rptr. at 364 . The arbitration provision provided that " "[a]ny controversy or claim arising out of or relating to this Agreement or the breach thereof shall be settled by arbitration in accordance with the Rules of the American Arbitration Association . . . and judgment upon any award rendered by the arbitrator may be entered in any court having jurisdiction thereof.' "Id at 591, 645 P.2d at 1195, 183 Cal. Rptr. at 363.

6. Southland originally removed the Keating action to federal district court, but it was remanded to the state court, presumably due to the lack of complete diversity between plaintiffs and all of the defendants. Id at $600-01,645$ P.2d at 1201, 183 Cal. Rptr. at 369. The various actions were consolidated in one proceeding after the franchisees filed umeuded complaints containing substantially similar allegations of misrepresentation in the sale and performance of the 7-Eleven franchises. Id at 592, 645 P.2d at 1196, 183 Cal. Rptr. at 364.

7. In-the alternative, the franchisees argued that if arbitration were to procecd, it should be on a classwide, rather than individual, basis. Id at 591, 645 P.2d at 1195, 183 Cal. Rptr. at 363.

8. The majority opinion was written by Justice Grodin of the Cahifornia Court of Appeal sitting by assignment of the clairperson of the judicial council pursuant to CAL. CONST. art. VI, §6. Chief Justice Bird and Justices Newman and Reynoso concurred in the court's opinion. Justice Grodin has since been appointed an associate justice of the California Supreme Court. L.A. Daily J., Dec. 3, 1982, \& 1, at 1, col. 6.

9. Cal. Corp. Code $\$ \S 31000-31516$ (West 1977 \& Supp. 1983).

10. 31 Cal. 3d at 595-604, 645 P.2d at 1198-204, 183 Cal. Rptr. at 366-72.

The issue of arbitration under the Franchise Investunent Law is currently on appeal to the 
that, in modeling the Franchise Investment Law after the Securities Act of $1933,{ }^{11}$ the California Legislature intended the Law to be interpreted in accordance with federal court decisions under the Act. ${ }^{12}$ The court rejected Southland's argument that the Federal Arbitration Act ${ }^{13}$ preempted state law and required enforcement of the arbitration provision. Although California law favors arbitration, the court noted that not all disputes are arbitrable. Thus, the court held that the Act did not preempt a statute that the state legislature, in accord with analogous federal policy, had enacted to provide nonwaivable judicial remedies. ${ }^{14}$

The court rejected the franchisees' argument that Southland had waived its right to arbitration. It found that there had been no "judicial litigation of the merits of arbitrable issues which [would waive] a party's right to arbitration." 15 Moreover, because the franchisees failed to demonstrate that they had been prejudiced by Southland's actions, the court held that the record fully supported finding that there had been no waiver. ${ }^{16}$

Applying the test for adhesion contracts announced in Graham $v$. Scissor-Tail, Inc. ${ }^{17}$ the court found that the 7-Eleven franchise agreements were adhesion contracts. However, the court held that this fact alone would not preclude Southland from enforcing the arbitration clause against the individual franchisees. The court reasoned that the clause was not oppressive as to the individual franchisees, and that arbitration generally is within the reasonable expectations of commercial parties. $^{18}$

U.S. Supreme Court, where the questions presented focus on (1) whether arbitration under the Federal Arbitration Act is impaired by imposing class action procedures on arbitration involving interstate commerce; and (2) whether the Franchise Investment Law violates the Supreinacy Clause by invalidating arbitration agreenents involving interstate commerce that are "valid, irrevocable and enforceable" under the Federal Arbitration Act. Appellant's Jurisdictional Statemeut at i, Southland Corp. v. Keating, 103 S. Ct. 721 (1983) (No. 82-500).

11. 15 U.S.C. $\S \S 77 \mathrm{a}-77 \mathrm{aa}$ (1976 \& Supp. V 1981).

12. Since arbitration clauses are invalidated when allegations of wrongdoing stem from violations of the Securities Act of 1933, Wilko v. Swan, 346 U.S. 427 (1953), the court argued by analogy that arbitration provisions should be invalidated when allegations of wrongdoing stem from violations of the California Franchise Investment Law. $31 \mathrm{Cal}$. 3d at 599, 645 P.2d at 1200, 183 Cal. Rptr. at 368.

13. 9 U.S.C. $\$ \$ 1-14$ (1976).

14. $31 \mathrm{Cal}$. 3d at 599, 645 P.2d at 1200, 183 Cal. Rptr. at 368. This Note addresses the Franchise Investment Law claims and federal preemption issues only as they relate to the solution proposed in this Note. See infra notes $116-23$ and accompanying text.

15. Id. at 607,645 P.2d at 1206, 183 Cal. Rptr. at 374 (emphasis in original) (quoting Doers v. Golden Gate Bridge, Highway \& Transp. Dist., 23 Cal. 3d 180, 188, 588 P.2d 1261, 1265, 151 Cal. Rptr. 837, 841 (1979)).

16. 31 Cal. $3 d$ at 608,645 P.2d at 1206, 183 Cal. Rptr. at 374.

17. 28 Cal. 3d 807, 817-19, 623 P.2d 165, 171-72, 171 Cal. Rptr. 604, 610-11 (1981) (per curiam).

18. 31 Cal. $3 d$ at 595, 645 P.2d at 1198,183 Cal. Rptr. at 366. 
While the court held the arbitration clause vahd as to the individual franchisees, it noted that the clause might still be oppressive if "used to insulate the drafter . . . froin any form of class proceeding, effectively foreclosing many individual claims." 19 The court thus recognized a pohicy of preventing a party with superior bargaining power from avoiding resolution of numerous small disputes by contractually protectimg itself froin classwide proceedings. In applying this pohicy to the facts in Keating, the court recognized that the arbitration clause may be invalid as to the class of franchisees when it oppressively foreclosed their ability to bring "any form of class proceeding." 20

Although the court noted the possibility of class oppression, it did not imvahidate the arbitration provision. Instead, recognizing the Cahforma policy favoring arbitration, the court balanced the competing policies and created the classwide arbitration procedure, despite the absence of any direct authority. In so doing, the court sought to remedy this class oppression through a procedure combining the advantages of both arbitration and class actions. ${ }^{21}$

The opmion briefly addressed the procedural problems that might arise under the newly created remedy. The court resolved these concerns by granting the trial court a significant degree of discretion in decidimg whether to order classwide arbitration. The supreme court directed the trial court to consider such factors as the appropriateness of class certification, the impact of court supervision on the arbitration proceeding, and the availability of consohdated arbitration ${ }^{22}$ as an alternative remedy. The trial court was also to consider the possibility of prejudice to the defendant in a classwide arbitration proceeding. ${ }^{23}$ Even though the trial court could order classwide arbitration, the supreme court gave the franchisor-defendant the option of rejecting it in favor of a class action.

\section{The Dissent}

Justice Richardson ${ }^{24}$ dissented from the court's holding that Franchise Investment Law claims are not subject to arbitration. He argued that clear national substantive law exists requirmg arbitration of the claims under the Federal Arbitration Act. ${ }^{25}$ To the extent that the state law conflicts with the federal Act, the law is void under the supremacy clause. In addition, Justice Richardson did not find the ar-

19. Id. at 610,645 P.2d at 1207,183 Cal. Rptr. at 375 .

20. Id.

21. Id. at $610-14,645$ P.2d at 1207-10, 183 Cal. Rptr. at 375-78.

22. See infra notes $42-50$ and accompanying text.

23. 31 Cal. 3d at 613-14, 645 P.2d at 1209-10, 183 Cal. Rptr. at 377-78.

24. Justice Mosk concurred in the dissenting opinion.

25. $31 \mathrm{Cal} .3 \mathrm{~d}$ at $614-20,645$ P.2d at $1210-14,183 \mathrm{Cal}$. Rptr. at 378-82. 
bitration clause oppressive ${ }^{26}$ because it did not "effectively deny relief to the weaker party [as an individual] in an adhesion contract"27 and because the stronger party was not trying to evade responsibility for its actions. ${ }^{28} \mathrm{Had}$ there been individual oppression, however, Justice Richardson would have invalidated the arbitration provision and ordered a judicial class action. ${ }^{29}$

II

\section{BACKGROUND LAW}

\section{A. Arbitration}

\section{Commercial Arbitration}

Commercial arbitration ${ }^{30}$ is a nnethod of dispute resolution by which the contracting parties agree to submit any contractual disagreeinent to an impartial tribunal ${ }^{31}$ and to accept its decision as binding. Most states recognize an agreement to arbitrate an existing dispute, and many states permit agreements to arbitrate future disputes. ${ }^{32}$

California's policy favoring arbitration is reflected in statutory ${ }^{33}$

26. Id. at 626,645 P.2d at 1217,183 Cal. Rptr. at 385 .

27. Id.

28. Id.

29. This Note follows the dissent to the cxtent that this Note adopts a judicial class action as the appropriate remedy where class oppression is found. See infra notes 105-23 and accompanying text. However, the dissent ignored the majority's extension of adhesion theory to class oppression. Instead, the dissent would allow a judicial action only when the arbitration provision bears oppressively on the individual, weaker party. $31 \mathrm{Cal}$. 3d at 626,645 P.2d at 1217, $183 \mathrm{Cal}$. Rptr. at 385. Because California law establishes that arbitration provisions in commercial contexts are seldom oppressive when enforced against an individual party, the dissent would virtually always uphold individual arbitration.

30. See generally R. Coulson, Business Arbitration-What You Need to Know (1980); M. Domke, The LaW and Practice of Commercial arbitration (1968); G. Goldberg, A LAWYer's Guide to Commercial ARbirration (1977). Arbitration under collective bargaining agreements is the other main category of contractual arbitration. See M. TROTTA, LABOR ARBITRATION 34-35 (1961). In addition, some states have enacted compulsory judicial arbitration statutes to resolve disputes involving small sums of money and to reduce trial court congestion. See, e.g., Cal. Civ. Proc. Code $\S \S 1141.10-32$ (West 1982 \& Supp. 1983).

31. How inpartial each individual arbitrator must be is not always clear. In California, individual arbitrators need not be completely neutral. See Dinong v. Superior Court, $120 \mathrm{Cal}$. App. 3d 300, 303, 174 Cal. Rptr. 590, 591 (1981). There may be a requirement of some impartiality of the arbitral tribunal as a whole, however. See Grahain v. Scissor-Tail, Inc., 28 Cal. 3d 807, 825-26, 623 P.2d 165, 176-77, 171 Cal. Rptr. 604, 615-16 (1981) (per curiam); Note, Graham v. Scissor-Tail, Inc.: Unconscionability of Presumptively Biased Arbitration Clauses Within Adhesion Contracts, 70 CALIF. L. Rev. 1014, 1039 (1982).

32. As of January 1, 1982, at least 42 states and the District of Columbia had adopted modem arbitration statutes that allow arbitration of future disputes. Appellee's Motion to Dismiss at 18 n.14, Southland Corp. (No. 82-500).

33. Act of April 22, 1927, ch. 225, 1927 Cal. Stat. 403 (codified as amended at CAL. Crv. PROC. CODE $\S \S 1280-1297$ (West 1982)). 
and case $^{34}$ law. California's arbitration statute allows only limited judicial interference with the arbitration process. A party may ask a court to compel arbitration, but once the order to arbitrate is made, the party opposing the decision may not take an immediate appeal..$^{35}$ Even after an arbitrator's final decision on the merits, the court's review norinally is limited to the validity of the order to arbitrate and to fraud or misconduct of the arbitrator. ${ }^{36}$ The arbitrator's decision on the merits is not a proper subject for judicial review. ${ }^{37}$

Arbitration has several important advantages over litigation. It is generally considered to be faster and it relieves court congestion. ${ }^{38}$ It is usually less costly, ${ }^{39}$ and it dispenses with judicial rules of evidence and transcripts. ${ }^{40}$ Because the arbitrators themselves are often experts in the area of dispute, the need for time-consuming expert testimony is reduced. The arbitrator is free to fashion a remedy consistent with the practical needs of the parties. ${ }^{41}$

\section{Consolidated Arbitration}

The increasing complexity of arbitrations and their mcreasing use m a variety of commercial settings have led some courts and state legislatures to permit consolidated arbitration. Consolidated arbitration allows several parties to be brought together in a single proceeding mvolving a common set of facts, even though the parties do not have a common agreement. ${ }^{42}$ In the typical case, $X$ sues $Y$ on a contract contaming an arbitration provision; $Y$ then sues $Z$ on a separate contract containing a similar provision and tries to bring $Z$ into the first arbitration proceeding. Consolidated arbitration allows all three disputants to come together in one proceeding, in which $Z$ may be found directly hable to $X$ despite the lack of contractual privity between them. ${ }^{43}$

34. Vernon v. Drexel Burnham \& Co., 52 Cal. App. 3d 706, 715, 125 Cal. Rptr. 147, 152 (1975).

35. Wheeler v. St. Joseph Hosp., 63 Cal. App. 3d 345, 353, 133 Cal. Rptr. 775, 780-81 (1976). See Cal. Civ. Proc. Code $\$ 1294$ (West 1982).

36. CAL. Civ. Proc. Code $\S 1286.2$ (West 1982).

37. Safeway Stores, Inc. v. Local 70, Bhd. of Teamsters, 83 Cal. App. 3d 430, 437, 147 Cal. Rptr. 835, 838-39 (1978).

38. Vernon v. Drexel Burnham \& Co., 52 Cal. App. 3d 706, 715-16, 125 Cal. Rptr. 147, 152 (1975).

39. Taylor v. Crane, 24 Cal. 3d 442, 452, 595 P.2d 129, 135, 155 Cal. Rptr. 695, 701 (1979); Madden v. Kaiser Found. Hosps., 17 Cal. 3d 699, 706-07, 552 P.2d 1178, 1182, 131 Cal. Rptr. 882, 886-87 (1976).

40. Bernhardt v. Polygraphic Co., 350 U.S. 198, 203 n.4 (1956).

41. See Mentschikoff, The Significance of Arbitration-A Preliminary Inquiry, 17 Law \& Contemp. Probs. 698, 707 (1952).

42. See, e.g., CAl. CIv. Proc. Code $\$ 1281.3$ (West 1982).

43. Although some courts have rejected consolidated arbitration due to the absence of direct statutory authority, Atlas Plastering, Inc. v. Superior Court, 72 Cal. App. 3d 63, 70-71, $140 \mathrm{Cal}$. Rptr. 59, $62-63$ (1977); accord Wm. C. Blanchard Co. v. Beach Concrete Co., 121 N.J. Super. 418, 429, 297 A.2d 587, 594 (1972); Hjelle v. Sornsin Constr. Co., 173 N.W.2d 431, $438-39$ (N.D. 1969), 
Various justifications have been advanced for the consolidated arbitration procedure. The one most commonly cited is that consolidated arbitration encourages efficiency and reduces the possibility of inconsistent awards. ${ }^{44}$ Although it is not a purely consensual nodel of arbitration, courts have held that consolidation does not impermissibly interfere with the parties' agreement because it is consistent with the parties' intent to arbitrate, and because it imposes on them a procedure only shightly different from that for which they contracted. ${ }^{45}$

In deciding whether to order consolidation, courts apply a two-tier test: whether the issues are substantially the same and whether a substantial right of a party will be prejudiced if consolidation is ordered. ${ }^{46}$ Where consolidation makes it possible to determine all the common issues in a single proceedimg involving all the interested parties, courts seldom find that consolidation prejudices the interests of the parties. ${ }^{47}$

In 1978, Califormia amended its arbitration statute to allow consol-

and other courts have rejected it as a matter of judicial discretiou, Gavlik Constr. Co. v. H.F. Campbell Co., 389 F. Supp. 551, 555-56 (W.D. Pa. 1975); Stop \& Shop Cos. v. Gilbane Bldg. Co., 364 Mass. 325, 329-30, 304 N.E.2d 429, 431-32 (1973); J. Brodie \& Son, Inc. v. George A. Fuller Co., 16 Mich. App. 137, 141-42, 167 N.W.2d 886, 888 (1969), some federal and state courts have ordered consolidated arbitration, Compania Espanola de Petroleos, S.A. v. Nereus Shipping, S.A., 527 F.2d 966, 974-75 (2d Cir. 1975), cert. denied, 426 U.S. 936 (1976); In re Czarnikow-Rionda Co., 512 F. Supp. 1308, 1309-10 (S.D.N.Y. 1981); In re Marine Trading Ltd., 432 F. Supp. 683, 685 (S.D.N.Y. 1977); Robinson v. Warner, 370 F. Supp. 828, 831 (D.R.I. 1974); see Annot., 64 A.L.R.3d 528 (1975) (discussing state cases dealing with the consolidation of arbitration proceedings).

As authority for ordering consolidated arbitration, federal courts have relied upon rule 81(a)(3) of the Federal Rules of Civil Procedure which makes the federal rules applicable to the Federal Arbitration Act to the extent that inatters of procedure are not specified in the arbitration statute. FED. R. CIV, P. 81(a)(3) ("In proceedings under Title 9, U.S.C., relating to arbitration ... these rules apply only to the exteut that matters of procedure are not provided for in those statutes"). Thus Rule 42(a), which states that "[w]hen actious involving a common question of law or fact are pending before the court, it may order a joint hearing or trial of any or all the matters in issue in the actions; it may order all the actions consolidated; and it may make such orders concerning proceedings therein as may tend to avoid unnecessary costs or delay," FED. R. CIV. P. 42(a), may be deeined as incorporated into the Federal Arbitration Act, Robinson v. Warner, 370 F. Supp. 828, 830-31 (D.R.1. 1974).

44. Grover-Dimond Assoc. v. American Arbitration Ass'n, 297 Minn. 324, 329, 211 N.W.2d 787, 789-90 (1973) (citing Vigo S.S. Corp. v. Marship Corp., 26 N.Y.2d 157, 167, 257 N.E.2d 624, 626, 309 N.Y.S.2d 165, 168, cert. denied, 400 U.S. 819 (1970), and CBS v. American Recording \& Broadcasting Ass'n, 414 F.2d 1326, 1329 (2d Cir. 1969)).

45. See Chariot Textiles Corp. v. Wannalancit Textile Co., 21 A.D.2d 762, 763-64, 250 N.Y.S.2d 493, 495 (1964) (Valente, J., dissenting) (per curiam). On appeal, the court of appeals reversed and adopted Judge Valente's dissenting opinion, 18 N.Y.2d 793, 795, 221 N.E.2d 913, 913, 275 N.Y.S.2d 382, 383 (1966).

46. James Stewart Polshek \& Assocs. v. Bergen County Iron Works, 142 N.J. Super. 516, 529, 362 A.2d 63, 70 (1976); Materials Int'l v. Manning Fabrics, 46 A.D.2d 627, 628, 359 N.Y.S.2d 812, 814 (1974) (per curiant); Grover-Dimond Assoc. v. American Arbitration Ass'n, 297 Minn. 324, 327, 211 N.W.2d 787, 789-90 (1973). See Domke, supra note 30, § 27.02 at 272-73.

47. Vigo S.S. Corp. v. Marship Corp., 26 N.Y.2d 157, 167, 257 N.E.2d 624, 626, 309 N.Y.S.2d 165, 168, cert. denied, 400 U.S. 819 (1970). 
idated arbitration when three conditions are met. ${ }^{48}$ First, each party to a consolidated arbitration must have an agreement to arbitrate with one or more of the other parties. Second, each dispute must arise from the same transaction or series of transactions. Fimally, a common issue of law or fact must create the possibility of conflicting rulings if the disputes are not consolidated. As with individual arbitration agreements, the judge is empowered to select an arbitrator if the parties cannot agree. ${ }^{49}$ The arbitration statute also gives the judge significant discretion. It provides that the judge is to "determine the rights and duties of the various parties to achieve substantial justice under all the circumstances." 50

\section{B. Class Actions}

The policies underlymg class actions are both procedural and substantive. When joinder is impractical because of the number of parties, class proceedings relieve the burden on both plamtiffs and courts of a multiplicity of mdividual suits. Class actions can make litigation feasible im cases where the potential recovery is too small to warrant individual prosecution. ${ }^{51}$ In addition, class actions prevent imconsistent judgments, avoid requiring the defendant to engage in inconsistent conduct toward multiple plaintiffs, and prevent excessive claims agaimst a limited fund. ${ }^{52}$ Finally, class actions serve a "public regulatory" function. They provide a judicial forum for claims that cannot be heard individually and allow an individual representative to assert claims that transcend private concerns. ${ }^{53}$

The specific procedural requirements for bringing class actions vary. The relevant California statute establishes only the general right to bring such actions. ${ }^{54}$ Consequently, the main development of California class action rules has been through case law, ${ }^{55}$ which has

48. Act of June 20, 1978, ch. 260, § 2, 1978 CAL. STAT. 543, 544-45 (codified at CAL. Clv. Proc. CODE $\S 1281.3$ (West 1982)).

49. Cal. Civ. Proc. Code $\$ 1281.3$ (West 1982). The judge then chooses the arbitrator in accordance with the procedures set forth in $\$ 1281.6$ of the California Civil Procedure Code. Id.

50. Id.

51. Daar v. Yellow Cab Co., 67 Cal. 2d 695, 714-15, 433 P.2d 732, 746, 63 Cal. Rptr. 724, 738 (1967). See also Danzig v. Superior Court, 87 Cal. App. 3d 604, 612, 151 Cal. Rptr. 185, 190-91 (1978).

52. 7A C. Wright \& A. Miller, Federal Practice and Procedure: Civil $\S 1773$ (1972).

53. See Developments in the Law-Class Actions, 89 HARV. L. REv. 1318, 1365-66 (1976) [hereinafter cited as Developments].

54. Section $\mathbf{3 8 2}$ of the California Civil Procedure Code provides that "when the question is one of a common or general interest, of many persons, or when the parties are numerous, and it is impracticable to bring them all before the court, one or more may sue or defend for the benefit of all." CAL. Civ. Proc. Code $\$ 382$ (West 1973).

55. See, e.g., Vasquez v. Superior Court, 4 Cal. 3d 800, 809, 484 P.2d 964, 969, 94 Cal. Rptr. 
modeled them on the federal procedures. ${ }^{56}$ Thus, in California as in federal courts, the judge must certify the class properly, ${ }^{57}$ and ensure that notice ${ }^{58}$ and representation ${ }^{59}$ are adequate and that the settlement is fair and reasonable to all class members. ${ }^{60}$ In general, California courts rely upon the ingenuity of the trial judge to develop procedures that are fair and expedient. ${ }^{61}$

\section{Adhesion Contracts}

An adhesion contract ${ }^{62}$ is a "standardized contract, which, imposed and drafted by the party of superior bargaining strength, relegates to the subscribing party only the opportunity to adhere to the contract or reject it." ${ }^{\prime 63}$ Courts recognize that such contracts do not reflect true equality of bargaining power. ${ }^{64}$ California courts have found adhesion contracts in consuner contexts, ${ }^{65}$ and recently in commercial

796,801 (1971) (requiring that plaintiffs establish the existence of an ascertainable class and a well-defined community of interest in questions of law and fact in order to maintain a class action).

56. See, e.g., La Sala v. American Sav. \& Loan Ass'n, 5 Cal. 3d 864, 872, 489 P.2d 1113, 1117, 97 Cal. Rptr. 849, 853 (1971) (applying federal class action rule).

Federal class actions are governed by rule 23 of the Federal Rules of Civil Procedure. In order to bring a class action, for four prerequisites of rule 23(a) (numerosity, commonahity, typicality, and adequacy of representation) unust be met, and the class inust fall within one of three categories of rule 23(b). Rule 23(b)(1) permits a class action where individual actions would impose incompatible standards of conduct on the party opposing the class or impair the interests of class meinbers not party to the individual actions. Rule 23(b)(2) permits a class action where the party opposing the class has acted or refused to act on grounds generally applicable to the class, and is limited to cases in which "final injunctive relief or corresponding declaratory relief with respect to the class as a whole" is appropriate. Finally, rule 23(b)(3) authorizes a class action where questions of law or fact common to the class predominate over questions affecting only individual nembers and where the class action device is superior to other methods of adjudication. Because members of a rule 23(b)(3) class are only loosely associated by common questions of law or fact, rather than by a preexisting or continuing legal relationship, it is less certain that they will be fully protected by the class proceeding. C. WRIGHT, THE LAW OF FEDERAL CourTs $\$ 72$, at 482 (4th ed. 1983). Thus, individual members may "opt out" of a rule 23(b)(3) action by requesting that they be excluded from the class. FED. R. Crv. P. 23(c)(2).

57. FED. R. CIV. P. 23(c)(1).

58. FED. R. CIV. P. 23(c)(2).

59. See Home Sav. \& Loan Ass'n v. Superior Court, 42 Cal. App. 3d 1006, 1010, 117 Cal. Rptr. 485, 487 (1974).

60. FED. R. Civ. P. 23(e); National Ass'n of Regional Medical Programs, Inc. v. Mathews, 551 F.2d 340, 344-45 (D.C. Cir. 1976), cert. denied, 431 U.S. 954 (1977). See also Mallick v. Superior Court, 89 Cal. App. 3d 434, 438, 152 Cal. Rptr. 503, 506 (1979).

61. Vasquez v. Superior Court, 4 Cal. 3d 800, 821, 484 P.2d 964, 977-78, 94 Cal. Rptr. 796, 809-10 (1971).

62. The term was introduced into the American legal vocabulary by Patterson, The Delivery of a Life-Insurance Policy, 33 HARv. L. REv. 198, 222 (1919). See also Kessler, Contracts of Adhesion-Some Thoughts About Freedom of Contract, 43 CoLUM. L. REv. 629, 631-32 (1943).

63. Neal v. State Farm Ins. Co., 188 Cal. App. 2d 690, 694, 10 Cal. Rptr. 781, 784 (1961) (Tobriner, J.) (mtroducing the definition to California law).

64. See Standard Oil Co. v. Perkins, 347 F.2d 379, 383 n.5 (9th Cir. 1965).

65. For a list of the various contexts in which consumer contracts have been found adhesive, 
contexts as well. ${ }^{66}$

The California Supreme Court has noted that "[t]o describe a contract as adhesive in character is not to indicate its legal effect."67 To determine that effect, California courts have devised a two-part disjunctive test. First, the court asks if the contract or any of its terms defeats the reasonable expectations of the weaker party. If it does, either because the weaker party has not had sufficient notice of its effect, $^{68}$ or because it harms the public interest, ${ }^{69}$ it will not be enforced. Second, if, in light of statutory law ${ }^{70}$ and public pohicy, ${ }^{71}$ the contract is found to be oppressive or unconscionable, the court will invalidate it regardless of whether the weaker party had notice of its effect. ${ }^{72}$

\section{III}

\section{ANALYSIS}

Keating is significant both for holding that adhesion contracts may be oppressive to a class and for creating the classwide arbitration remedy. In recognizing class oppression, however, the court provided few guidelines for determining when it exists. Not only is the classwide arbitration remedy unsupported by legal authority or public policy, but it also frustrates the policies underlying both arbitration and class actions.

see Sybert, Adhesion Theory in California: A Suggested Redefinition and Its Application to Banking, 11 LoY. L.A.L. REv. 297, 303 (1978).

66. Graham v. Scissor-Tail, Inc., 28 Cal. 3d 807, 818 n.13, 623 P.2d 165, 171 n.13, 171 Cal. Rptr. 604, 610 n.13 (1981) (per curiam).

67. Id. at 819,623 P.2d at 172, 171 Cal. Rptr. at 611 (citing Wheeler v. St. Joseph Hosp., 63 Cal. App. 3d 345, 357, 133 Cal. Rptr. 775, 783 (1976)).

68. Id. at 820 n.18, 623 P.2d at $172-73$ n.18, 171 Cal. Rptr. at 612 n.18. See also Gray v. Zurich Ins. Co., 65 Cal. 2d 263, 271-72, 419 P.2d 168, 173, 54 Cal. Rptr. 104, 109 (1966); Steven v. Fidehty \& Casualty Co., 58 Cal. 2d 862, 882-83, 377 P.2d 284, 296-98, 27 Cal. Rptr. 172, 184-86 (1962) (ambiguous terms in air travel insurance contracts purchased before read defeat reasonable expectations of insured).

69. See, e.g., Tunkl v. Regents of the Univ. of Cal., 60 Cal. 2d 92, 101-02, 383 P.2d 441, 44647, 32 Cal. Rptr. 33, 38-39 (1963) (adhesive exculpatory contract between patients and hospitals for medical services affected the public interest detrimentally); Tobriner \& Grodin. The Individual and the Public Service Enterprise in the New Industrial State, 55 CAL1F. L. REV. 1247 (1967) (outlining the expansion of legal concepts to impose special duties on parties in areas affected by the public interest).

70. California has adopted the Uniform Commercial Code's definition of unconscionability from U.C.C. $\$ 2-302$ in CAL. CIv. CODE $\$ 1670.5$ (West Supp. 1982).

71. See Tunkl v. Regents of the Univ. of Cal., $60 \mathrm{Cal}$. 2d 92, 101-02, 383 P.2d 441, 446-47, 32 Cal. Rptr. 33, 38-39 (1963).

72. See, e.g., Jacklich v. Baer, 57 Cal. App. 2d 684, 693-94, 135 P.2d 179, 183-84 (1943). The California Supreme Court recently applied this second rule in Graham v. Scissor-Tail, lnc., where the court found a commercial adhesion contract unconscionable. $28 \mathrm{Cal} .3 \mathrm{~d} \mathrm{807,826-27,623 \textrm {P.2d }}$ 165, 177, 171 Cal. Rptr. 604, 616 (1981) (per curiam). 


\section{A. Adhesion Theory-Expansion of the Theory of Oppression}

In deciding whether the franchise contract in Keating could be enforced, the supreine court applied adhesion principles in a new way. The court noted that under ordinary circuinstances the contract would be fully enforceable since a provision for arbitration in a commercial context is not oppressive and is "quite common and reasonably to be anticipated."73 But in considering the collective effect of an adhesive arbitration provision the court found that unfair advantage ${ }^{74}$ amounting to oppression ${ }^{75}$ might result if the provision were invoked to block an otherwise appropriate class action. Tlus, while not oppressive on an individual basis, the agreement could be considered oppressive as to the class of franchisees.

As a justification for its class oppression rule, the Keating court stressed the value of class actions. ${ }^{76}$ The court emphasized that class actions: (1) eliminate the possibility of repetitious litigation; (2) provide a method of obtaining redress for claims that would otherwise be too sinall to warrant individual litigation; and (3) may prevent a wrongdoer from retaining the benefits of its wrongful conduct. ${ }^{77}$ Moreover, other commentators have noted that class actions may serve a public regulatory function by allowing large groups of persons to challenge existing law or practices. ${ }^{78}$ Thus, class actions further both procedural and substantive concerns. ${ }^{79}$

An arbitration clause precluding class actions will lose these advantages. Identical disputes inust be resolved individually and inconsistencies are likely because principles of collateral estoppe ${ }^{80}$ and stare decisis ${ }^{81}$ do not apply. As Keating indicates, the lack of a class remedy might foreclose many sinall individual claims, even though the quickness and efficiency of arbitration normally allows dispute resolution of smaller claims. Thus, an arbitration clause may allow the franchisor to continue its allegedly improper conduct toward at least some, if not all, of the franchisees. ${ }^{82}$

73. 31 Cal. 3d at 595, 645 P.2d at 1198, 183 Cal. Rptr. at 366.

74. Cf. id. at 593-94, 645 P.2d at 1197, 183 Cal. Rptr. at 365 (noting the special protection given to franchisees in CAL. CoRP. CODE $\$ \S 31000-31516$ (West 1977)).

75. Id. at 608-10, 645 P.2d at 1206-07, 183 Cal. Rptr. at 374-75.

76. Id. at 609,645 P.2d at $1206-07,183$ Cal. Rptr. at 374-75.

77. Id.

78. See, eg., supra note 53 and accompanying text.

79. See Developments, supra note 53, at 1354-72 (arguing that, by facilitating the litigation of individual small claims through the class action device, the courts are able to enforce the policies behind causes of action that might otherwise not be brought).

80. $31 \mathrm{Cal}$. 3d at 609, 645 P.2d at 1207, $183 \mathrm{Cal}$. Rptr. at 375.

81. Wetsel v. Garibaldi, 159 Cal. App. 2d 4, 12-13, 323 P.2d 524, 530 (1958).

82. It is not clear from the opinion into which type of class action Keating would fall. Because Keating involved standardized contracts, however, it might well qualify under FED R. Crv. 
Although the Keating court advanced sound reasoning for its class oppression rule, it did not specify under what conditions the rule would apply in future cases. Rather, the court merely set forth two conditions, which if satisfied might lead to a finding of class oppression. First, the arbitration clause must insulate the drafter of the adhesion contract from any class proceeding. ${ }^{83}$ Second, use of the arbitration clause must operate to foreclose many individual claims because of the small size of each claim. ${ }^{84}$ Although the court stated two necessary conditions, the court did not indicate whether these conditions would be sufficient for a finding of class oppression; instead, the court left that finding to the discretion of the trial court, even when both conditions are met. ${ }^{85}$

The Keating court was disappointingly vague about the conditions necessary for a finding of class oppression. The court missed an opportunity to guide the trial court by not stating clearly when such a finding would be appropriate. In responding to the court's tentative suggestions, a trial court may in the exercise of its discretion misapply the class oppression concept, or it may attempt to avoid finding class oppression altogether.

\section{B. Classwide Arbitration-The New Remedy}

After finding that an arbitration provision denying "any form of class proceeding" ${ }^{86}$ could be oppressive, the Keating court did not imvalidate the arbitration provision and order a class action remedy. Instead, it gave the trial court discretion to determine the appropriate remedy, ${ }^{87}$ but eniphasized that the preferred remedy would be classwide arbitration. ${ }^{88}$

P. 23(b)(1)(A) as a situation where as a practical matter the defendant must treat all plaintiffs similarly. See generally 7A C. WRIGHT \& A. MILLER, supra note $52, \S 1773$. Thus, if no action is brought at all the defendant may be able to continue its improper conduct with respect to all franchises. On the other hand, if individual actions are brought, the defendant might have to change its conduct with respect to all franchisees despite the absence of a finding that it was acting improperly with respect to all.

83. $31 \mathrm{Cal}$. 3d at 610,645 P.2d at 1207,183 Cal. Rptr. at 375.

84. Id.

85. Id. at 613,645 P.2d at $1209,183 \mathrm{Cal}$. Rptr. at 377.

86. $31 \mathrm{Cal}$. 3d at 610,645 P.2d at 1207, $183 \mathrm{Cal}$. Rptr. at 375. See supra notes 19-21 and accompanymg text.

87. Id. at 591, 645 P.2d at 1195, 183 Cal. Rptr. at 363. The Keating court left open the possibility that once a class had been certified, the action might proceed on some basis other than classwide arbitration. Specifically, the court mentioned consolidated arbitration and class action. It is unlikely, however, that consolidation would be an appropriate alternative remedy smce all parties must be present in a consolidated proceeding, and by definition, a class is not certified unless it is impracticable to join all parties in one proceeding. Similarly, a class action would seldom be ordered under Keating because it is not appropriate unless the drafting party requests the class action. Id. at 614,645 P.2d at 1210, $183 \mathrm{Cal}$. Rptr. at 378 . Because arbitration is nornally in the interest of the drafting party, it is unlikely that it would opt for a class action.

88. 31 Cal. 3d at 612-13, 645 P. 2d at 1209-10, 183 Cal. Rptr. at 377-78. 
The remedy of classwide arbitration, however, lacks a sound basis in either law or policy. The court misapplied adhesion contract principles and relied on an inappropriate analogy to consolidated arbitration. The remedy thus fashioned fails to take into account the contractual expectations of the parties or to keep arbitration efficient and inexpensive.

\section{The Court's Legal Justifications}

The court found indirect authority for the classwide arbitration remedy by looking to case law and statutes providing for consolidated arbitration. It noted that "a party nnay be forced into a coordinated arbitration proceeding in a dispute with a party witlı whom lie has no agreement, before an arbitrator lie had no voice in selecting and by a procedure he did not agree to." 89 Since classwide arbitration involves less judicial intrusion into the arbitration process than consolidated arbitration, the court reasoned that classwide arbitration should be acceptable.

In noting one way in which classwide arbitration is less onerous than consolidated arbitration, the Keating court ignored the ways in which classwide arbitration is inore onerous. Consolidated arbitration requires that all parties be present at the hearing; classwide arbitration does not allow all parties to represent themselves. It therefore frustrates the contractual interests of all absent parties. Moreover, classwide arbitration does not afford disputants the full range of protections which a class action would provide. While allowing plaintiffs to opt out $^{90}$ would minimize this problem, it is not clear that all plaintiffs should have a right to opt out, at least when the dispute fits within the guidelines of Rule 23(b)(1) or (b)(2) of the Federal Rules of Civil Procedure. ${ }^{91}$ To allow class meinbers to opt out when more is at stake than the inoney damages usually at issue in a Rule 23(b)(3) class action ${ }^{92}$ would defeat the purpose of producing one binding determination of the merits of the suit. It might also raise the danger of subjecting the defendant to incompatible standards of conduct toward those franchisees who had opted out and those wlio liad brought the class arbitration..$^{93}$

89. Id. at 612,645 P.2d at 1209,183 Cal. Rptr. at 377.

90. Id. Under the circumstances discussed in Keating, an opt ont provision would not have been of much use to the individual franchisees. Because the classwide arbitration was premised on the individual claims being too small to arbitrate, presumably those plaintiffs who had opted out would have been denied a remedy entirely.

91. See supra note 56.

92. See supra note 56.

93. See Developments, supra note 53, at 1487-89 (arguing against allowing plaintiffs to opt out of Rule 23(b)(1) or (b)(2) class actions). See also 7A C. WRIGHT \& A. MiLler, supra note 52, 


\section{The Court's Policy Justifications}

The court's remedy in Keating is as lacking in policy justifications as it is in legal support. The reinedy may be counterproductive and ineffective in achieving the policies the court had hoped to promote.

The Keating court reviewed the policies favoring both arbitration and class actions raised in Vernon v. Drexel Burnham \& Co. ${ }^{94}$ and other cases. ${ }^{95}$ Without further discussion, lowever, the court concluded on the authority of Vernon that a class action should not be used to avoid arbitration. ${ }^{96}$ In Vernon, the court of appeal held that the policies favoring arbitration prevail over those favoring class actions for three reasons: (1) the substantive law of contracts takes precedence over the procedural law of class actions; (2) the freedom of parties to contract is highly valued; and (3) arbitration is faster and less expensive than class litigation. ${ }^{97}$

None of the three reasons that supported arbitration in Vernon support the decision reached in Keating. First, by suggcsting that the substantive law of contracts overrides the procedural law of class actions, the Keating court contradicted its discussion of the substantive, public regulatory role of class actions on which it partially based its finding of class oppression. ${ }^{98}$ Were class actions simply a procedural convemience to promote efficiency, creation of the classwide arbitration remedy would be unnecessary because the arbitration forum already provides the advantages of efficiency and economy. However, as the Keating court acknowledged, class actions do serve a substantive purpose. The policies underlymg class actions sliould not be subordmated to those favoring arbitration.

Second, the policy of upholding the parties' freedom to contract is mapplicable in an adhesion contract setting, ${ }^{99}$ where by definition the bargain was not freely made. Moreover, imposing a newly created pro-

$\$ 1772$ (noting that when an action can be classified under either Rule 23(b)(1) or (b)(3), (b)(1) has been held to apply to avoid the apphicability of the opt out provision).

94. 52 Cal. App. 3d 706, 125 Cal. Rptr. 147 (1975).

95. Harris v. Shearson Hayden Stone, Inc., 82 A.D.2d 87, 441 N.Y.S.2d 70 (1981); Frame v. Merrill Lynch, Pierce, Fenner \& Smith, Inc., 20 Cal. App. 3d 668, 97 Cal. Rptr. 811 (1971).

96. 31 Cal. 3d at 610,645 P.2d at 1207, 183 Cal. Rptr. at 375.

97. 52 Cal. App. 3d at 715-16, 125 Cal. Rptr. at 152-53.

98. See supra notes 77-79 and accompanying text.

99. The court held that the contract was adhesive because it was a standard form imposed by a stronger party upon a weaker party. However, even though the franchisee's only choice was to accept the contract without inodification or to reject it altogether, the court notcd that the sontract would be enforceable under ordinary circumstances because individual franchisees had a reasonable expectation that there would be a contractual arbitration provision. $31 \mathrm{Cal}$. 3d at 595, 645 P.2d at 1198, 183 Cal. Rptr. at 366. See Note, supra note 31, at 1027-28, 1047, for an argument that in Graham v. Scissor-Tail, Inc., 28 Cal. 3d 807, 623 P.2d 165, 171 Cal. Rptr. 604 (1981) (per curiam), the "weaker party" had substantial unused bargaining power that the court's decision, by protecting his interests, did not force him to exercise. That criticism cannot be applied here. No 
cedure on parties who did not consent to it nay itself be inconsistent with their freedom to contract.

Third, when conducted on a classwide basis, arbitration is unlikely to remain inexpensive and efficient. It will increase the burden on the judge and divide authority between the judge and the arbitrator. The majority conceded that the trial court would have to make initial determinations regarding certification and notice, supervise the arbitration to safeguard the rights of absent class members, and oversee disinissal or settlement. ${ }^{100}$ The dissent pointed out that additional burdens on the court would include, among others, continued supervision of the adequacy of representation, and review of the proceedings to determine if the settlement was fair and reasonable. ${ }^{101}$ Moreover, the division of authority over the proceedings between the judge and the arbitrator would entail many procedural complications. ${ }^{102}$ The majority's statement that "[a] good deal of care, and imgenuity, would be required to avoid judicial intrusion upon the merits of the dispute, or upon the conduct of the proceedings themselves and to minimize complexity, costs, or delay" 103 is an understatement. While some efficiencies will still survive in classwide arbitration, ${ }^{104}$ these small gains seem insufficient to outweigh the protections of a judicial class action.

\section{IV}

\section{A Proposed Solution}

The two chief defects in Keating - the uncertainty created by its discretionary class oppression rule, and its weakly justified classwide arbitration remedy - can be corrected by ordering a class action ${ }^{105}$

court policy can force the weaker party to make use of bargaining power he simply does not possess.

100. 31 Cal. 3d at 613,645 P.2d at 1209, 183 Cal. Rptr. at 377.

101. Id. at 622-23, 645 P.2d at 1215-16, 183 Cal. Rptr. at 383-84 (Richardson, J., concurring and dissenting). These burdens on the court include, among others: supervisiou of notification to class members; continued supervision of the adequacy of representation; approval of settlements; and review of the proceedings to determine if the settlement was fair and reasonable.

102. But see Note, Classwide Arbitration: Efficient Adjudication or Procedural Quagmire?, 67 VA. L. REv. 787, 806-09 (1981). That Note argued that the arbitrator can perform the administrative tasks related to class certification, and that, with minimal imterference from the judge, classwide arbitration would continue to be efficient. It is unlikely, however, that an arbitrator, who might indeed be an expert in a particular industry, would have the necessary expertise to decide complex issues of class certification.

103. 31 Cal. $3 d$ at 613,645 P.2d at 1209,183 Cal. Rptr. at 377.

104. These imclude the flexible rules of procedure and freedoin from being boimd by precedent. See Note, supra note 102, at 813 . However, when these informal procedures are present in an arbitration that is also a class proceeding, they may hurt, rather than help. Absent parties, in particular, are uot given the full due process protections they would receive in a judicial action.

105. Both the majority and dissent briefly considered and then rejected this solution. $31 \mathrm{Cal}$. 3d at 610, 626, 645 P.2d at 1207, 1217, 183 Cal. Rptr. at 375, 385. As already noted, however, the majority rejected a judicial class action because it incorrectly concluded that the pohicy favoring 
when there is a finding of class oppression. The class action remedy also avoids the preemption problems raised by the dissent.

\section{A. The Oppression Test}

Under the solution suggested here, three separate conditions must be satisfied to mvalidate an arbitration provision under the class oppression rule. First, the challenged agreement must include an adhesive arbitration clause. Second, the weaker party must be able to satisfy the standing prerequisites for bringing a class action. ${ }^{106}$ Third, either the claims of mdividual class members must be so small that it would be impractical for each member to resort to individual arbitration, or the claim must challenge the legality of the contract itself and thus call for public, not private, adjudication. The proposed solution thus incorporates considerations suggested by the Keating court, but uses them as elements in a definite, predictable test.

The first requirement of the proposed test-a finding that the underlying agreement is an adhesion contract-requires only the analysis already apphied in California. However, adhesiveness alone is not sufficient to imvalidate an arbitration provision; ${ }^{107}$ the provision must also be found to be oppressive. ${ }^{108}$ Denial of the class action supplies the necessary oppression, but only if that remedy would have been available otherwise. ${ }^{109}$ Thus, the second element of the test is that a judicial class action must be an appropriate remedy im the absence of the arbitration provision.

The third condition may be satisified in either of two ways. Where the plaintiffs' claims are so sinall that no incentive exists to seek individual redress, ${ }^{110}$ an arbitration provision is oppressive because it effectively forecloses many individual claims. ${ }^{11}$ If, however, the claims of

arbitration outweighed that favoring class actions. See supra notes 95-104 and accompanying text. The dissent rejected a judicial action except in cases where the arbitration clause is oppressive as to individual parties. See supra note 29 and accompanying text.

106. See supra note 56.

107. But see Sterk, Enforceability of Agreements to Arbitrate: An Examination of the Publlc Policy Defense, 2 CARDozo L. REv. 481, 487 (1981) (arguing that all arbitration clauses in adhesion contracts should be held invalid).

108. See supra notes $67-72$ and accompanying text.

109. Part of Keating's class oppression rule was based on the court's determination that the arbitration clause alone precluded "any form of class proceeding." Unless the plaintiff can maintain a judicial class action in the absence of the arbitration provision, the arbitration clause would not be the cause of the preclusion of class proceedings, and thus would not be oppressive.

110. This condition was of course one of the two suggested by the Keating court. It may be even harder to meet than the nornal threshold showing required under FED. R. Clv. P. 23(b)(3) since arbitration's lower cost inakes it more likely that a plaintiff could pursue even a small claim in an arbitral forum.

I11. 31 Cal. 3d at 610, 645 P.2d at 1207, I83 Cal. Rptr. at 375.

A recent New York decision that addressed this situation ordered individual arbitration. 
the parties are large enough to warrant individual arbitration, there is an alternative third elennent-the existence of a claim calling for public adjudication. When the underlying nature of the claim is one that deinands public, rather than private, adjudication, an arbitration provision that prevents a judicial class action is oppressive. ${ }^{112}$ The need for judicial resolution of statutory ineaning or important public policy claims should override the policies favoring arbitration without regard to the size of individual claims.

\section{B. The Class Action}

The traditional class action procedure proinotes both fairness and administrability. Fairness is promoted in two ways. First, the class action gives full protection to absent class members by assuring them full due process protection. ${ }^{113}$ Second, the class action will generally benefit the weaker party to the adhesion contract, ${ }^{114}$ one of the chief aims of the law on adhesion contracts.

The class action also avoids the administrative problems inherent in classwide arbitration because of its hybrid, partly judicial and partly arbitral forum. ${ }^{115}$ This solution entrusts all of the responsibilities of a class proceeding to the judiciary, which is experienced in handling them. Consolidation of the remedy into a single forum might lead to a more efficient and economical disposition than would classwide arbitration.

Harris v. Shearson Hayden Stone, Inc., 82 A.D.2d 87, 94-95, 441 N.Y.S.2d 70, 75-76 (1981) (citing Vernon v. Drexel Burnham \& Co., 52 Cal. App. 2d 706, 125 Cal. Rptr. 147 (1975)). However, the dissenting opinions noted significant policies favoring judicial class actions. They recognized that individual arbitration would not be effective to redress wrongs where "the loss to each inember of the class inay well be so miniscule as to make it scarcely practical to resort to arbitration." Id. at 100, 441 N.Y.S.2d at 79 (Blooin, J., dissenting). One dissenter notcd a strong public pohicy in favor of judicial class actions under such circumstances. Id. at 97, 441 N.Y.S.2d at 77 (Sandler, J., dissenting). Another dissenter noted that to prevent the judicial class action "is to immunize the practice followed by [the defendant] from scrunity by anyone." Id. at 101, 441 N.Y.S.2d at 79 (Bloom, J., dissenting).

112. For a similar statement of this view, see Sterk, supra note 107. His formulation of the test focuses on the concept of doing jnstice between the parties: "Public policy should be invoked to prevent arbitration when at issue is a legislative expression or a basic case law principle designed for soine purpose other than to foster justice between the parties to the dispute." Id. at 483 (footnote omitted). Sterk's test is independent of the other three factors stated in this Note. He would allow public policy to prevent arbitration in a variety of areas including, among others: child custody; antitrust; patent law; and bankruptcy. Id. at 500-16.

113. See supra notes $57-60$ and accompanying text.

114. See supra note 87 and accompanying text.

115. See Stop \& Shop Cos. v. Gilbane Bldg. Co., 364 Mass. 325, 329-30, 304 N.E.2d 429, 43132 (1973) (raising the same objection to consolidated arbitration) (quoting Cavanaugh v. McDonnell \& Co., 357 Mass. 452, 457, 258 N.E.2d 561, 564 (1970)). 


\section{Avoiding Federal Preemption Problems}

The proposed remedy avoids the conflict with federal law that the dissent in Keating considered dispositive. Justice Richardson argued that the arbitration clause in Keating involved interstate commerce and therefore was governed by the Federal Arbitration Act, not by Cahforma's Franchise Investment Law. ${ }^{116}$ The Federal Arbitration Act provides generally that all agreeinents to arbitrate are vahd, irrevocable, and enforceable. ${ }^{17}$ However, even if the Act is read as favoring arbitration absolutely, its own terins provide that arbitration can be avoided "upon such grounds as exist at law or equity for the revocation of any contract." 118 Because the class oppression rule proposed in this Note applies revocation principles applicable to all adhesion contracts, it avoids conflict with the Act.

Finally, the Federal Arbitration Act exphicitly exempts from its coverage employment contracts of workers engaged in interstate commerce. ${ }^{119}$ The United States Supreme Court has attributed this exemption to the fact that one of the parties characteristically has little bargaiming power. ${ }^{120}$ Various types of statutes have also been held to require judicial supervision where a weaker party to a contract requires protection $^{121}$ or where the public interest calls for judicial scrutiny. ${ }^{122}$ The presence of any one of these factors separately might not be sufficient to warrant state preemption of the Federal Arbitration Act. ${ }^{123}$ However, when the proposed test for class oppression has been satisfied, all the factors are present and there is a sound basis for avoiding arbitration without conflicting with federal law.

\section{CONCLUSION}

In Keating v. Superior Court, the California Supreme Court created a new remedy for the weaker party to an adhesion contract, recognizing that classwide arbitration nuay be available when an arbitration provision in a contract blocks an otherwise appropriate class action. The court balanced the interests in favor of class actions and those $\mathrm{m}$

116. 31 Cal. 3d. at 614, 645 P.2d at 1210, 183 Cal. Rptr. at 378 (Richardson, J., dissenting).

117. 9 U.S.C. $\$ 2$ (1976).

118. Id

119. 9 U.S.C. \& 1 (1976).

120. Prima Paint Corp. v. Flood \& Conklin, 388 U.S. 395, 402 n.9 (1975) (interpreting 9 U.S.C. $\S 1)$.

121. Claims under the federal securities, antitrust, and bankruptcy laws have been held nonarbitrable. Appellee's Motion to Dismiss at 17, Southland Corp. (No. 82-500).

122. See Sterk, supra note 107 , at 483 .

123. But see United Nuclear Corp. v. General Atomic Co. 93 N.M. 105, 597 P.2d 290 (allowing state antitrust statute to bar arbitration under the Federal Arbitration Act), cert. denied, 444 U.S. 911 (1979). 
favor of arbitration and concluded that in some instances this combined procedure might be the appropriate reinedy. While acknowledgmg that the remedy contained inherent difficulties, the court justified its decision by einploying the same reasoning that Winston Churchill used to defend democracy. Classwide arbitration, the court concluded, must be evaluated, not in relation to soine ideal, but in relation to its alternatives. ${ }^{124}$

This Note suggests that the better alternative is to invahidate the arbitration provision and to allow the plaintiffs to proceed with a judicial class action. The court correctly recognized the importance of allowing plamtiffs to bring a judicial class action. But by creating a hybrid remedy to give effect to the policies underlying judicial class actions, the court acted without statutory or contractual authority and created an unwieldy, confusing procedure that effectively negates the plaintiffs' right to a class action - a procedure inore consistent with California and federal law and policy.

Elizabeth P. Allor*

124. 31 Cal. 3d at 613, 645 P.2d at 1209, 183 Cal. Rptr. at 377.

* A.B. 1981, Stanford University; third-year student, Boalt Hall School of Law, University of California, Berkeley. 